\title{
DUSTBATHING IN RELATION TO EARLY PECKING EXPERIENCE IN GAME PHEASANTS (Phasianus colchicus)
}

\author{
K. S. VESTERGAARD, M. BILDSØE \\ The Royal Veterinary and Agricultural University, Department of Animal Science and Animal Health, \\ Division of Ethology and Health, Frederiksberg C, Denmark
}

\author{
Received January 12, 1999 \\ Accepted March 31, 1999
}

\begin{abstract}
Vestergaard K. S., M. Bildsøe: Dustbathing in Relation to Early Pecking Experience in Game Pheasants (Phasianus colchicus). Acta Vet. Brno 1999, 68: 141-148.

Studies on domestic chicks have indicated that preferences for dustbathing substrates are related to early pecking experience before full dustbathing behaviour has appeared. In this study we investigated if this was also the case in game pheasant (Phasianus colchicus), a close relative of fowl. Pheasant chicks were kept as pairs in wire floored cages and given either 2 min or 5 min pecking experience by simultaneous presentation of peat and sand on days $2-11$. On days 13 and 14 they were tested for dustbathing performance during $30 \mathrm{~min}$ simultaneous presentation of sand, peat and feed. Chicks on the 5 min treatment had a higher pecking rate $(\mathrm{P}<0.01)$ and therefore gained more experience with the pecking substrates than chicks on the 2 min treatment. Furthermore, chicks on the 5 min pecking treatment dustbathed more in the substrates than those on the 2 min treatment $(\mathrm{P}<0.05)$. Generally, chicks preferred to peck at peat rather than at sand $(\mathrm{P}<0.02)$ and they also preferred to dustbathe in peat $(\mathrm{P}<0.03)$.

In the 2 min group dustbathing in the substrates and early overall pecking rate on days 2-11 at the substrates were positively correlated, with a strongly increased correlation coefficient by day 8 . In the 5 min group the correlations between pecking at either sand or peat and dustbathing in sand peaked on day 4. During the dustbathing tests three chicks that had no or very little experience of pecking the substrates preferred to dustbathe in food. We suggest that like domestic chicks game pheasant chicks imprint on dustbathing substrates by pecking at them during the first days of life.

Phasianus colchicus, dustbathing, pecking, development
\end{abstract}

Recent studies have indicated that early pecking experience is related to later preferences for dustbathing substrates in domestic chicks (Vestergaard and Baranyiová 1996). The more the chicks pecked at a substrate (peat or sand) day 3 of life the more dustbathing was later performed on that substrate during a choice test where the substrates were presented simultaneously. It is therefore likely that early pecking experience with inedible loose substrates leads to an imprinting like process whereby the pecked substrate becomes preferred for dustbathing later in life. With the proper early control of access to pecking and dustbathing substrates not only sand but also feathers and straw may be preferred for dustbathing (Vestergaard and Lisborg 1993; Sanotra et al. 1995). These substrates were either attached (feathers) or with a too large particle size to provide the usual cleaning effect as a salient substrate for dustbathing (Liere and Siard 1991). Dustbathing functions to remove old stale uropyial gland oil from the plumage and thereby improve feather and down structure and consequently enhance the insulation capacity of the plumage (Borchelt and Duncan 1974; Liere and Bokma 1987; Liere and Siard 1991). In accordance with the functional properties of sand, preference studies have shown that sand is preferred for dustbathing and early pecking over straw and feathers (Sanotra et al. 1995). Generally, fowl show ingrained preferences for dustbathing substrates; for example peat is preferred over sand in inexperienced birds (Petherick et al. 1995) and similar 
results have been found for red junglefowl (Gallus gallus spadiceus), the ancestor of all domestic breeds of fowl (Vestergaard and Hogan 1992).

Knowledge about the imprinting process is interesting in itself. However, it is also relevant to the feather pecking problem in domestic fowl since, for example early dust-imprinting treatment of domestic chicks may reduce feather pecking later in life very considerably (Johnsen et al. 1998). In that study the feather peckers in the control groups consistently pecked feathers during the rest of their life although they had the same environment as the birds in the dust imprinting groups from 4 weeks of age. This indicated that dustbathing plays a causal role in feather pecking and that the proper early experience is essential. Thus knowledge about the normal dust imprinting process is significant in order to avoid the development of feather pecking in fowl and game pheasants and possibly other gallinaceous species kept in captivity. Indeed, in the rearing of game pheasants feather pecking and its associated cannibalism is a major problem that has to be solved (Hoffmeyer 1969; Cain et al. 1984). In Denmark the use of bits (a small plastic ring placed between the upper and lower bill) or bill trimming by means of a hot blade to prevent feather pecking damage is being faced out and so is rearing in darkness which has also been used to control feather pecking. There is therefore an urgent demand for a solution whereby game pheasants can be reared safely without the use of bits and darkness. Some aspects of dust perception seem to be ingrained ("prefunctional"); for example the visual stimuli from peat are sufficient to elicit dustbathing in inexperienced domestic fowl 2-3 months of age (Petherick et al. 1995), and such ingrained responses may be dominating in some species.

Early experience may not only influence feather pecking in game pheasants, but also influence later amount of feather care which may be essential for survival in the wild. In the study by Johnsen et al. (1998) the rearing of domestic chicks to secure a proper dust imprinting on sand had a lasting beneficial effect since these birds dustbathed approximately four times more than the controls. If this is also true for game pheasants a proper rearing with a normal dust perception development would most likely improve the plumage condition and lead to a better survival after release in nature.

For game pheasants there is no information on the development of the dust perception mechanism and the relative role of ingrained responses and early pecking experience, although it would be of relevance in fivding a solution to the feather pecking problem and to increase plumage care. In the present study we therefore examined the significance of early pecking experience for the development of the dust perception mechanism.

We controlled dustbathing and pecking in pairs of pheasant chicks kept in wire floored cages. Half of the pairs were given $5 \mathrm{~min}$ and the other pairs $2 \mathrm{~min}$ pecking experience with sand and peat on day 2-11 of life, and all pairs were then tested for dustbathing in a dustbathing choice test day 13-14. We hypothesised that more pecking experience in the 5 min pecking treatment as compared to the 2 min treatment would lead to a better association with the substrates for dustbathing and consequently more dustbathing in the substrates during the tests. We also hypothesised that chicks that pecked more at a substrates during the pecking tests would be better imprinted on that substrate and consequently dustbathe more in it during the tests. To reveal when an asssociation between pecking at the substrates and dustbathing in them appeared, and how much pecking experience that was required to make such an association a number of correlation analyses were made on the cumulative counts for consecutive days of pecking.

Materials and Methods

Animals and housing

On the day of hatching 51 pheasant chicks were provided from a breeder and placed in wire cages as pairs (24 pairs and three extra chicks to compensate for mortality during the first days). The cages (45¥45¥45 cm) had masonite backsides and sides to prevent visual contact between neighbouring pairs. Ceilings, floors and cage fronts 
were made of wire mesh $(1 ¥ 3 \mathrm{~cm})$. Light came from a 40 watt lamp that was shared between two neighbouring cages. They were placed above the cage partition at $50 \mathrm{~cm}$ distance from the wire floor. The lights were on from 07.00 and until $19.00 \mathrm{hr}$. Each cage was provided with a small water bottle placed on the front wire and a trough $(8 ¥ 10 ¥ 2 \mathrm{~cm})$ covered with wire mesh to prevent dustbathing in them. The food was a standard rearing feed for pheasants. The food structure was fine grained until day 6 and thereafter the coarser "pellet cross". In each cage one chick, the focal chick, was marked with black speed-marker on the head and back. The chicks were kept in two rooms with 12 pairs in each. Room temperature was kept at $20^{\circ} \mathrm{C}$ and in each cage a heating lamp that gave heat but no light ("Elstein", 60 watt) was hanging down from the ceiling to provide extra heat. Until day 7 of life a small piece of cardboard $(12 ¥ 12 \mathrm{~cm})$ was placed under the heating lamp to provide insulation and solid support for the chicks (see Vestergaard and Lis borg, 1993 for further details). Because of mortality and a procedural error we ended up with data from 8 pairs on the 2 min treatment and with 11 pairs for pecking data and 12 pairs for dustbathing data in the 5 min treatment.

Experimental procedures

From day 2 and until day 11 of life pecking tests were carried out in the home cages. Half of the pairs in each room were given a 5 min pecking test and the remaining pairs a 2 min pecking test. A small metal box, $6 ¥ 18 ¥ 3.5 \mathrm{~cm}$ that had three separate and equally large spaces was used for the simultaneous presentation of peat and fine grained yellow sand (from Ærø island, Denmark). The peat and sand was placed in the two side spaces, whereas the middle space was empty and covered with wire to prevent the chicks from pecking mixed substrates (during pecking the substrates were spilled out of the side spaces). Day 2-7 a glass plate was placed in front of the pecking box to provide support for the chicks. Thereafter they could easily stand on the wire floor. Only the focal chick in each pair was recorded for pecking activity. We recorded all pecks at either substrate using direct observation and prepared data sheets. During the pecking tests we also recorded numbers of leg scratching and dustbathing attempts (vertical wing-shakes) directed at each of the substrates (see Vestergaard and Hogan 1992). The observer sat $1 \mathrm{~m}$ from the front of the cage while observing the chicks. One chick was observed at a time starting in a different room each day, and within each room the pairs were always observed in the same order. All tests were carried out between 12.00 and $15.00 \mathrm{hr}$.

Dustbathing choice tests of 30 min duration were carried out day 13 or 14 of life in a room adjacent to that of the home cages. The test cages were similar to the home cages, but longer ( $90 ¥ 45 ¥ 45 \mathrm{~cm}$ ) and provided with two 60 watt lamps placed $50 \mathrm{~cm}$ above the wire floors. The room temperature was kept at $33^{\circ} \mathrm{C}$. The substrates for dustbathing were presented in wooden trays $(19 ¥ 18 ¥ 4 \mathrm{~cm})$. We presented a tray with the feed ("pellet cross") in the middle and the trays with peat and sand to either side, alternating between the right or left side between each successive pair to be tested. As a measure of dustbathing activity we recorded by direct observation and the use of prepared data sheets all vertical wing-shakes (Kruijt 1964) performed by the focal chick. One observer observed two focal chicks simultaneously. We also recorded time to latency for the first vertical wing-shake and which substrate was used for each vertical wing-shake. Some times dustbathing appeared on the wire floor while the bird was pecking a substrate. In these cases the vertical wing-shake was recorded together with a note of which substrate that was pecked. Half of the pairs on each treatment was tested day 13 and the remaining pairs day 14. All dustbathing choice tests were started between 11.00 and $15.00 \mathrm{~h}$ which is in accordance with the diurnal rhythm of dustbathing in both fowl (Vesterg a ard 1982; Vestergaard et al. 1990) and Japanese quail (Coturnix coturnix japonica; Schein and Statkiewicz 1983). In order to habituate the chicks to being moved and tested we placed each pair $8 \mathrm{~min}$ in the test cage every day after the pecking tests from day 6 of life. During these habituation sessions there were no substrates in the test cages.

Statistic analysis

Substrate preference for pecking and the effect of experience ( 5 min versus 2 min pecking tests) were analysed by means of an ANOVA with pecking experience as independent factor and pecking rate according to substrate as a repeated measurement. The data did not deviate significantly from a normal distribution $(\mathrm{P}>0.05)$. Preferences for dustbathing substrate were analysed by means of the Wilcoxon test or the Sign test. The effect of treatment on the amount of dustbathing was tested by the Mann-Whitney $U$-test. Correlations between pecks and dustbathing were analysed by the Spearman rank correlation coefficient. How exactly this was done appears in the legend to Fig. 3.

\section{Results}

Pecking tests

Pecking at each substrate generally increased with age in chicks on both the 5 and 2 min treatment (Fig. 1). Furthermore, an analysis of the overall pecking rates from day 2 to 11 (Fig. 2) revealed a significantly higher rate of pecking by the chicks on the 5 min treatment (ANOVA, $\mathrm{F}_{1,17}, \mathrm{P}<0.01$ ), and overall there was a significantly higher rate of pecks that were directed at peat as compared to sand (ANOVA, $\mathrm{F}_{1,17}, \mathrm{P}<0.02$ ). By day 11 there were on 


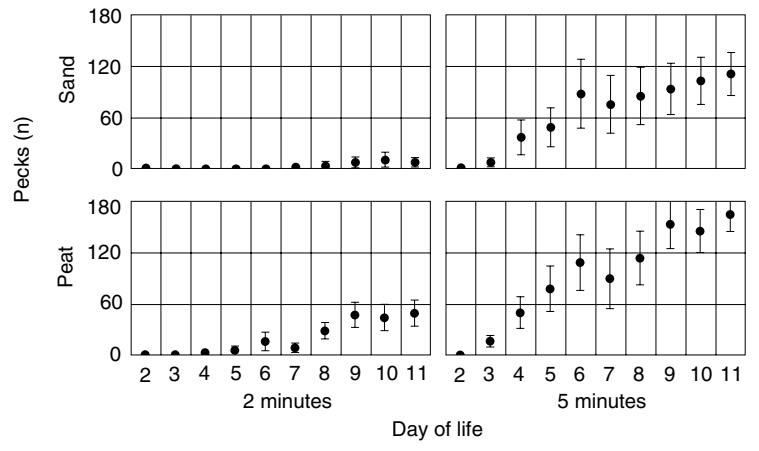

Fig. 1. Development of pecking at sand and peat in chicks on the $2 \mathrm{~min}$ and 5 min treatments (mean number of pecks per 2 min or per $5 \mathrm{~min} \pm \mathrm{SE}$, respectively).

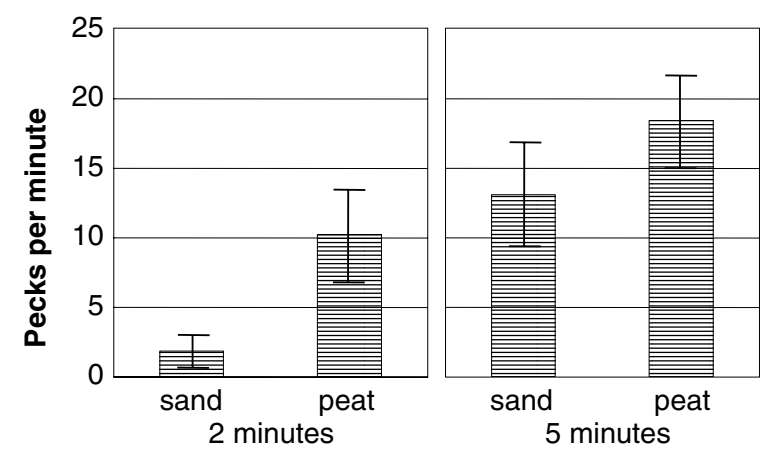

Fig. 2. Average pecking rates at sand and peat by chicks on the $2 \mathrm{~min}$ and 5 min treatments (overall number of pecks per min $\pm \mathrm{SE}$ ). The analysis (ANOVA) revealed that the chicks pecked more at peat than at sand $(\mathrm{P}<0.02)$, and that chicks on the 5 min treatment had an overall higher pecking rate than those on the 2 min treatment $(\mathrm{P}<0.01)$.

Table 1.

Dustbathing directed at the different substrates by chicks on the $2 \mathrm{~min}$ and $5 \mathrm{~min}$ treatments (average number \pm SE of vertical wing-shakes). Dustbathing in peat includes dustbathing on the wire while pecking at peat ( 3 chicks; 8,1 and 1 vertical wingshakes, respectively). In all other cases the chick had entered the tray with the substrate while performing vertical wing-shaking.

\begin{tabular}{|l|c|c|}
\hline & \multicolumn{2}{|c|}{ Treatment } \\
\hline Substrate & 2 minutes & 5 minutes \\
\hline Sand & $0 \pm 0$ & $3.6 \pm 2.7$ \\
\hline Peat & $14.8 \pm 4.6$ & $21.6 \pm 3.8$ \\
\hline Sand + peat & $14.8 \pm 4.6$ & $25.1 \pm 3.7$ \\
\hline Feed & $9.9 \pm 6.7$ & $0 \pm 0$ \\
\hline
\end{tabular}

average 32 pecks per min in the chicks on the 5 min treatment and 12 pecks per min in chicks on the 2 min treatment (Fig. 2). This corresponds to a total average pecking experience of 1575 pecks (920 at peat and 655 on sand) and 236 pecks (201 at peat and 35 at sand) per chick on the $5 \mathrm{~min}$ and 2 min treatment, respectively.

During the pecking tests some birds were scratching the floor and also some birds performed a few vertical wing-shakes on the floor. Scratching occurred in 9 of the focal chicks on the 5 min treatment (average: 15. 3) and in 4 of the focal chicks on the 2 min treatment (average: 8.5). Vertical wing-shakes occurred in 4 focal chicks on the 5 minute treatment (average: 2. 2 vertical wing-shakes) and in one focal chick (1 vertical wing-shake) in the 2 min treatment.

Dustbathing choice tests

During the dustbathing choice tests most chicks dustbathed in one or both trays with substrates (Table 1). In a few cases ( $\mathrm{n}=3$ chicks) dustbathing was performed on the floor while the chick pecked at the peat. In that case dustbathing was also considered related to peat because we knew from other experiments that pecking a substrate and dustbathing are closely associated (Vestergaard and Baranyiová 1996; Vestergaard and Lisborg 1993). On average chicks on the $5 \mathrm{~min}$ treatment performed more dustbathing in the dustbathing substrates (ignoring dustbathing in the feed) than those on the 2 min treatment (MannWhitney $U$-test; $\mathrm{U}=23.5, \mathrm{P}<0.03)$. This was also the case when dustbathing on the wire floor was included (Mann-Whitney $U$-test, $\mathrm{U}=$ $22.5, \mathrm{P}<0.03)$. The average numbers of vertical wing-shakes were 14.8 and 25.1 for chicks on the $2 \mathrm{~min}$ and $5 \mathrm{~min}$ treatment, respectively. Dustbathing in the tray with feed only occurred in 3 chicks on the 2 min treatment. 
Two of these birds had never pecked the substrates during the pecking test and the remaining bird did not peck the substrates before 8 days of age. When including dustbathing in the feed there was almost the same amount of dustbathing in the $2 \mathrm{~min}$ and 5 min treatment (averages were 24.7 and 25.1 vertical wing-shakes, respectively).

In the chicks on the 5 min treatment dustbathing was more frequent in peat than in sand (Wilcoxon tests, $\mathrm{P}<0.01$ ) and a similar trend was found in the chicks on the 2 min treatment where 6 out of 8 focal chicks dustbathed more in peat than in sand. Thus a majority of all the chicks preferred peat over sand for dustbathing (Sign test, $\mathrm{P}<0.002$ ). Only 4 focal chicks on the 5 min treatment and none on the 2 min treatment dustbathed in sand (Table 1). The latencies to start dustbathing during the tests were $305 \pm 102 \mathrm{sec}$ for the chicks on the $2 \mathrm{~min}$ treatment and $270 \pm 64 \mathrm{sec}$ for the chicks on the 5 min treatment.

\section{Associations between early pecking and dustbathing}

The results of the analysis for correlations between dustbathing in the substrates (sand + peat) and the overall rate for pecking at sand + peat appear in Fig. 3. In the chicks on the 2 min treatment the correlation between pecking and dustbathing was low until day 7 of life and thereafter the values became high and significant with the highest values day 9 and $11(\mathrm{R}$ $r_{s}=0.957 ; \mathrm{P}<0.002$ for both days). An additional analysis where pecking at sand and dustbathing in sand, and pecking in peat and dustbathing in peat were analysed separately gave similar but less significant results. Finally pecking at sand and dustbathing in peat was also highly correlated from day 8 of life $\left(\mathrm{R} \mathrm{r}_{\mathrm{s}}=0.74-0.77 ; \mathrm{P}<0.05\right)$.

For chicks on the 5 min treatment no significant results were found Fig. 3. Correlations between pecking at the substrates (peat + sand) when analysing the correlations during pecking tests and dustbathing in the substrates (number of when analysing the correlations vertical wing-shakes in peat + sand) during the dustbathing choice between dustbathing in sand + peat tests. The analysis was carried out for each day of pecking by using with total pecking at the substrates. cumulated values which reflects the total pecking experience The only significant result was obtained until each day.

found for correlation between pecking at peat and dustbathing in sand with peak value for correlation on day $4\left(\mathrm{R}_{\mathrm{s}}=0.83 ; \mathrm{P}<0.001\right)$.

\section{Discussion}

The main result of this study was that the amount of early pecking experience with sand or peat was of significance for dustbathing in these substrates later on. Chicks with a larger experience ( $5 \mathrm{~min}$ treatment) pecked at the substrates with a higher rate, and also dustbathed more in them than chicks that were given less time $(2 \mathrm{~min})$ to peck each day of the tests. These results are similar to those from a previous study on domestic chicks (experiment 2 in Vestergaard and Baranyiová 1996). The dustbathing and scratching that occasionally occurred during pecking tests supports that this pecking is related to the development of the dustbathing perceptual mechanism, and it has earlier been demonstrated that prolonged pecking tests (30 min) day 10-15 regularly leads to dustbathing on a plate of glass or the wire floor in domestic chicks (Vestergaard and Baranyiová 1996). 
Furthermore, in the present study pecking at the substrates and later dustbathing in them was positively and significantly correlated. In bobwhite quail (Colinus virginianus) Borchelt and Overmann (1975) also found that early pecking on days 1-6 into sand had a strong influence on the development of dustbathing from day 7 of life. The effect was much less pronounced if these chicks were only allowed to peck into the sand day 1-3 or day 4-6. Pecking experience on day 2 as compared to day 4 only resulted in faster development of dustbathing. In that study swalllowing and mandibulation of the substrates were essential for the effects on dustbathing to appear, and also in the present study on pheasants and the study on domestic chicks (Vestergaard and Baranyiová 1996) the chicks swallowed and mandibulated the substrates while pecking at them. For the development of the perceptual mechanisms of the feeding system pecking followed by swallowing and its postingestional nutritional consequences are necessary for an association to be formed between the pecked substrate and the feeding (or hunger) system (Hogan 1973), and this may similarly be the case for dustbathing, except that the absence of nutrition in the substrate may be essential for a substrate to be perceived as dust for dustbathing. However, in this study while pecking at the food chicks may potentially have been imprinted on the feed as a dustbathing substrate as indicated by the chicks that preferred to dustbathe in feed during the dustbathing tests. Dustbathing while pecking at food is a well known behaviour in caged hens with no access to a dustbathing substrate (Vestergaard 1994), and the present study on pheasants suggests that such an association may be formed during early development when no salient substrate for dustbathing has been pecked. However, further research is needed before any conclusion can be made.

Another interesting finding in the present study was that peat was preferred over sand both for early pecking and for dustbathing. This indicates that like red junglefowl (V e sterga ard and Hogan 1992) and domestic fowl (Petherick and Duncan 1989) game pheasants show prefunctional preferences among likely dust substrates. In the study on domestic chicks (Vestergaard and Baranyiová 1996) the analysis of correlation between early pecks during 5 min pecking tests and later dustbathing revealed that very early experience (day 3) was essential for the association between the pecked substrate and dustbathing to be formed, and that there was a sensitive period, because the correlations for pecking at later days were smaller and non-significant. In the present study the main result was that the combined pecking at peat and sand was correlated with dustbathing in these substrates later on in the 2 min treatment; there were no clear associations for either sand or peat between the amount of pecking at a substrate and later dustbathing in it as found for domestic chicks. Thus it seems that the pheasant chicks to a higher degree than the domestic fowl generalize between sand and peat as being both suitable for dustbathing once they have obtained pecking experience with both as for example indicated by the positive correlation between pecking at peat and dustbathing in sand in the chicks on the 5 min treatment. For the 2 min chicks the peak correlations appeared later (day 8-9) than in the study on domestic chicks. The chicks on the 2 min treatment gained a much less experience of pecking at the substrates than the chicks on the 5 min treatment and probably the 2 min tests were too short to obtain sufficient pecking experience by day 3 . Thus the comparison between dustbathing by the 2 min and 5 min treatment revealed that 2 min pecking tests gave too little experience for a full dustbathing response, and this also explains why more pecking by some of the 2 min chicks resulted in more dutbathing and consequently the positive correlation between pecking and dustbathing.

The general lack of significant correlation between pecking and dustbathing in the chicks on the 5 min treatment was surprising considering that a clear association had been found in domestic chicks. It may be, however, that only very limited experience of pecking at peat 
was sufficient for a full association between peat and dustbathing to be established and consequently no correlation could be revealed. This explanation is supported by the fact that peat was preferred for dustbathing and that already by day 4 the chicks on the 5 min treatment had obtained much more pecking experience than the chicks on the 2 min treatment at day 8 .

The main result, i.e. that early pecking experience influence later dust perception is a finding that is of interest for the further research on feather pecking in game pheasants (see Johnsen et al. 1998; Lis borg and Vestergaard 1997). Furthermore, for a bird in nature a perfect plumage is essential for insulation, flight and signalling (Middleton 1991) and consequently for reproduction and survival. When no early imprinting on a salient substrate for dustbathing has happened the amount of dustbathing may be considerably reduced (Johnsen et al. 1998) and consequently plumage condition may be impaired and the survival and reproduction reduced. A final point is that low performance of dustbathing, e.g. because of an aberrant development (Vesterg a ard et al. 1993) may lead to stress asf found in domestic hens in which dustbathing was thwarted (Vestergaard et al. 1997).

\section{Popelení ve vztahu k časnému zobání u bažantů (Phasianus colchicus)}

Studie provedené na kuřatech ukázaly, že preference pro substrát k zobání mají vztah $\mathrm{k}$ časné zkušenosti získané předtím, než se popelení plně vyvine. V této studii jsme sledovali, zda je tomu tak i u mlád’at bažanta (Phasianus colchicus), blízkého příbuzného kura domácího. Bažantí kuřata byla chována $\mathrm{v}$ párech $\mathrm{v}$ drátěných klecích. Jako substrát $\mathrm{k}$ popelení jim byla předkládána rašelina a písek na 2 anebo $5 \min$ od 2 . do 11 . dne po vylíhnutí. Ve 13. a 15. dnu byl u nich proveden test popelení, a to tak že jim na 30 min byly předloženy substráty rašelina, písek a krmná směs. Kuřata $s$ předchozí zkušeností a 5min expozicí substrátům do něj zobala častěji $(\mathrm{P}<0.01)$, tj. měla větší zkušenost se zobáním substrátu než kuřata $\mathrm{s}$ expozicí pouze 2 min. Kuřata po $5 \mathrm{~min}$ expozici se v substrátech popelila víc než kuřata po 2 min expozici $(\mathrm{P}<0.05)$. Obecně, bažantí kuřata preferovala zobání rašeliny než písku $(\mathrm{P}<0.02)$ a preferovala i popelení $\mathrm{v}$ rašelině $(\mathrm{P}<0.002)$.

Ve skupině kuřat s 2 min expozicí substrátům a časným zobáním v nich (od 2. do 11. dne) byly popelení a zobání v pozitivní korelaci a vzestupem korelačního koeficientu v 8. dnu. Ve skupině s 5 min expozicí byla korelace mezi zobáním rašeliny či písku a popelením pozitivní již 4 . dne. Během testů popelení 4 kuřata, která měla minimální zkušenost se substráty, preferovala k popelení krmivo. Výsledky ukazují, že podobně jako u kura domácího i u bažanta dochází ke vtištění na substrát k pozdějšímu popelení v prvních dnech po vylíhnutí.

\section{Acknowledgements}

This study was supported by a grant from the Danish hunters association and the Association of Game keepers in Denmark. We thank Malene Michel for taking well care of the birds and for careful observations.

\section{References}

BORCHELT, P. L., DUNCAN, L. 1974: Dustbathing and feather lipid in bobwhite quail (Colinus virginianus). Condor 76: 471-472

BORCHELT, P. L., OVERMANN, S. R. 1975: Development of dustbathing in bobwhite quail. II. Effects of early pecking experience. Devel. Psychobiol. 8: 417-423

CAIN, J. R., WEBER, J. M., LOCAMY, T. A., CREGER, C. R. 1984: Grower diets and bird density effects on growth and cannibalism in ring-necked pheasants. Poult. Sci. 63: 450-457

HOFFMEYER, I. 1969: Feather pecking in pheasants - an ethological approach to the problem. Dan. Rev. Game Biol. 6: 1-36

HOGAN, J. A. 1971: The development of a hunger system in young chicks. Behaviour 39: 128-201 
JOHNSEN, P. F., VESTERGAARD, K. S., NØRGAARD-NIELSEN, G. 1998: Influence of early rearing conditions on the development of feather pecking and cannibalism in domestic fowl. Appl. Anim. Behav. Sci. 60: $25-41$

KRUIJT, J. P. 1964: Ontogeny of social behaviour in Burmese red junglefowl (Gallus gallus spadiceus). Behav. Suppl. 12: 1-201

LIERE, D.W., van, BOKMA, S. 1987: Short-term feather maintenance as a function of dustbathing in laying hens. Appl. Anim. Behav. Sci. 18: 197-204

LIERE, D.W., van, SIARD, N., 1991: Towards an understanding of litter bathing quality in hens. In: Proceedings of a Symposium of the Society for Veterinary Ethology: Applied Animal Behaviour: Past, Present and Future (Ed. by M. C. Appleby, R. I. Horrell, J. C. Petherick, S. M. Rutter), pp. 132-133. Potters Bar, Herts: Universities Federation for Animal Welfare.

LISBORG, L., VESTERGAARD, K. S. 1997: Preventive effects of a new rearing method on feather pecking in pheasants (Phasianus colchicus). In: Proceedings of the Second International Conference on Environmental Enrichment, Copenhagen 21-25 August 1995 (Ed. by B. Holst), pp. 188-194. Copenhagen: Copenhagen Zoo.

MIDDLETON, A. M. A. 1991: Feather care. In: The Cambridge Encyclopedia of Ornithology. Brooke (Ed. by M. T. Birkhead), pp. 137-145. Cambridge: Cambridge University Press.

PETHERICK, J. C., DUNCAN, I. J. H. 1989: Behaviour of young domestic fowl directed towards different substrates. Br. Poult. Sci. 30: 229-238

PETHERICK, J. C., SEAWRIGHT, E., WADDINGTON, D., DUNCAN, I. J. H., MURPHY, L. B. 1995: The role of perception in the causation of dustbathing behaviour in domestic fowl. Anim. Behav. 49: 1521-1530

SANOTRA, G. S., VESTERGAARD, K. S., AGGER, J. F., LAWSON, L. G. 1995: The relative preferences for feathers, straw, wood-shavings and sand for dustbathing, pecking and scratching in domestic chicks. Appl. Anim. Behav. Sci. 43: 263-277

SCHEIN, M. W., STATCHIEWICZ, W. R. 1983: Satiation and cyclic performance of dust-bathing by Japanese quail (Coturnix coturnix japonica). Appl. Anim. Ethol, 10: 375-383

VESTERGAARD, K. 1982: Dustbathing in the domestic fowl - diurnal rhythm and dust deprivation. Appl. Anim. Ethol. 8: 487-495

VESTERGAARD, K. S. 1994: Dustbathing and its relation to feather pecking in the fowl: motivational and developmental aspects. Dissertation, The Royal Veterinary and Agricultural University, Copenhagen, $150 \mathrm{p}$.

VESTERGAARD, K. S., BARANYIOVÁ, E. 1996: Pecking and scratching in the development of dust perception in young chicks. Acta Vet. Brno 65: 133-142

VESTERGAARD, K., HOGAN, J. A. 1992: The development of a behavior system: Dustbathing in the Burmese red junglefowl. III. Effects of experience on stimulus preference. Behaviour 121: 215-230

VESTERGAARD, K., HOGAN, J. A., KRUIJT, J. P. 1990: The development of a behavior system: Dustbathing in the Burmese red junglefowl I. The influence of the rearing environment on the organization of dustbathing. Behaviour 112: 99-116

VESTERGAARD, K. S., LISBORG, L. 1993: A model of feather pecking development that relates to dustbathing in the fowl. Behaviour 126: 291-308

VESTERGAARD, K. S., SKADHAUGE, E., LAWSON, L.G. 1997: The stress of not being able to perform dustbathing in laying hens. Physiol. \& Behav. 62: 413-419 